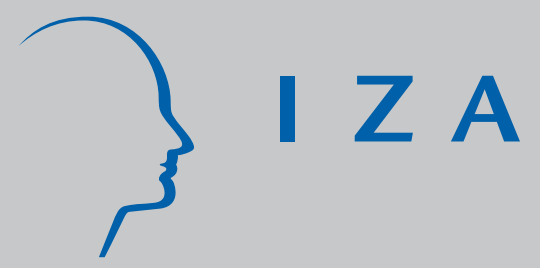

IZA DP No. 937

Fiscal Policy, Economic Integration and Unemployment

Wolfgang Eggert

Laszlo Goerke

November 2003 


\title{
Fiscal Policy, Economic Integration and Unemployment
}

\author{
Wolfgang Eggert \\ University of Konstanz, \\ CoFE and CESifo \\ Laszlo Goerke \\ Johannes Gutenberg University of Mainz, \\ CESifo and IZA Bonn
}

\author{
Discussion Paper No. 937 \\ November 2003
}

\author{
IZA \\ P.O. Box 7240 \\ D-53072 Bonn \\ Germany \\ Tel.: +49-228-3894-0 \\ Fax: +49-228-3894-210 \\ Email: iza@iza.org
}

This Discussion Paper is issued within the framework of IZA's research area Internationalization of Labor Markets. Any opinions expressed here are those of the author(s) and not those of the institute. Research disseminated by IZA may include views on policy, but the institute itself takes no institutional policy positions.

The Institute for the Study of Labor (IZA) in Bonn is a local and virtual international research center and a place of communication between science, politics and business. IZA is an independent, nonprofit limited liability company (Gesellschaft mit beschränkter Haftung) supported by Deutsche Post World Net. The center is associated with the University of Bonn and offers a stimulating research environment through its research networks, research support, and visitors and doctoral programs. IZA engages in (i) original and internationally competitive research in all fields of labor economics, (ii) development of policy concepts, and (iii) dissemination of research results and concepts to the interested public. The current research program deals with (1) mobility and flexibility of labor, (2) internationalization of labor markets, (3) welfare state and labor market, (4) labor markets in transition countries, (5) the future of labor, (6) evaluation of labor market policies and projects and (7) general labor economics.

IZA Discussion Papers often represent preliminary work and are circulated to encourage discussion. Citation of such a paper should account for its provisional character. A revised version may be available on the IZA website (www.iza.org) or directly from the author. 
IZA Discussion Paper No. 937

November 2003

\section{ABSTRACT \\ Fiscal Policy, Economic Integration and Unemployment ${ }^{*}$}

In this paper fiscal policy is examined for an open economy characterised by unemployment due to efficiency wages. We allow for capital and firm mobility in a model where the government chooses the level of wage, source-based capital and profit taxation. The taxing choices of governments are analyzed in scenarios which differ with respect to the constraints imposed on the set of available taxes and on the mobility of firms. As a general result, the welfare loss from labour market imperfections increases when tax bases become internationally mobile, which suggests an increasing relevance of domestic labour-market reforms when tax bases become global.

JEL Classification: H21, J41, J65

Keywords: optimal taxation, efficiency wages, unemployment

Corresponding author:

Laszlo Goerke

Department of Economics (FB 03)

Johannes Gutenberg University of Mainz

55099 Mainz

Germany

Email: Laszlo.Goerke@uni-mainz.de

\footnotetext{
* We thank Clemens Fuest, Rupert Sendlhofer, as well as participants of a seminar in Göttingen, a CESifo Workshop on Public Economics in Munich, the APET conference in Paris, the EEA annual meeting in Venice, the IIPF congress in Helsinki, and the SGVS meeting in Bern for helpful comments.
} 


\section{Introduction}

It is a core result of the literature on tax competition that decentralised decision-making by countries leads to an inefficient choice of tax policies when the taxing ability of governments is limited by geographic borders. In such an environment, the only feasible form of capital taxation is source-based. However, this form of taxation typically distorts the production decisions of firms. From this observation the literature often concludes that the welfare losses from decentralised fiscal decision-making can only be avoided by delegation of fiscal decisions to a supranational institution, or by the harmonisation of tax rates. ${ }^{1}$ In general, the respective analyses presume competitive labour markets.

The initial hypothesis of the present contribution is that unemployment has a notable effect on the gains and losses from tax harmonisation. This theoretical claim is motivated by the evidence summarised in Table 1. Including all 15 EU-member states and Switzerland into our sample, it can be noted from the first row of Table 1 that 11 of these countries supported further measures of tax coordination in the recent past. ${ }^{2}$ While Luxembourg, Switzerland and Austria tended to oppose tax coordination, Belgium and the UK took intermediate positions. Dividing our sample of 16 countries into three (almost) equal-sized groups $(5,5,6)$, according to the prevailing level of unemployment, we find that the three countries which viewed tax harmonisation sceptically, plus the Netherlands and Portugal, make up the group which is characterised by the lowest unemployment rates. This suggests that a better national labour market performance enables countries to pursue a competitive policy on the international capital market and, hence, induces them to oppose measures of tax harmonisation. There will, of course, be other determinants of a country's attitude towards tax harmonisation. For example, there is a recent literature which rationalises the view that especially countries with a relatively large financial sector may find it profitable to engage in competition for mobile capital (Eggert and Kolmar 2002, Huizinga and Nielsen 2003). Rows three and four in Table 1 provide support for this view.

In this paper, we concentrate on the impact of unemployment. Adopting the efficiency wage framework by Shapiro and Stiglitz (1984), the paper makes three contributions: it represents, to our knowledge, the first analysis of tax competition in an efficiency

\footnotetext{
${ }^{1}$ For excellent surveys of the tax competition literature with perfect labour markets see Wilson (1999), Haufler (2001a), Oates (1999). See also Fuest, Huber and Mintz (2003).

${ }^{2}$ Any indicator of a country's attitude towards tax harmonisation is arbitrary to some degree. An operational measure which we have used in Table 1 is the willingness to agree to the introduction of a minimum tax on interest income. See European Commission (1998) and European Commission (2001). For the purpose of this paper, tax harmonisation and tax coordination are regarded as synonyms.
} 


\begin{tabular}{l|ccc} 
Criterion & & & \\
\hline $\begin{array}{l}\text { Attitude towards } \\
\text { tax harmonization }\end{array}$ & sceptical & intermediate & positive \\
& L, SW, A & UK, B & DK, FI, F, D, GR, \\
Unemployment & low, I, NL, P, ES, S \\
& A, L, NL, SW, P & intermediate & hK, D, IR, S, UK \\
Financial Intermediation: & & & B, FI, F, GR, I, ES \\
- number of employees & high & intermediate & \\
- value-added & AR, L, NL, SW, UK & A, F, D, I & DK, FI, GR, ES, P, S \\
& high & intermediate & low \\
& A, B, L, SW, UK & DK, D, I, NL, ES & FI, F, GR, IR, P, S
\end{tabular}

A-Austria, B-Belgium, DK-Denmark, FI-Finland, F-Frankreich, D-Germany, GR-Greece, IR-Ireland, I-Italy, L-Luxembourg, NL-Netherlands, P-Portugal, ES-Spain, S-Sweden, SW-Switzerland, UK-United Kingdom (for data sources see the Appendix A).

Table 1: Attitude to Tax Harmonisation, Unemployment, and Size of Financial Sector.

wage model with unemployment. ${ }^{3}$ In particular, the paper provides a workhorse model for analysing issues of optimal taxation in the presence of labour market imperfections. Moreover, our analysis indicates that inefficiencies on the labour market and inefficiencies caused by tax competition are 'additive' in the sense that their adverse welfare effects mutually intensify each other. The reason is that governmental choice of capital taxes in an open economy is generally constrained by the downward pressure on taxes caused by tax competition. As a consequence, the scope for fiscal policy to counteract the imperfections on the national labour markets is limited. Coordination in tax matters is, thus, the more beneficial the more pronounced the distortions on the domestic labour market are. Our result, hence, rationalises the empirical observations of Table 1. Finally, we distinguish a setting with mobile capital but immobile firms and a world in which capital and firms can migrate. To our knowledge, the present paper is the first which allows for a characterisation of the economic mechanisms that determine the choice of tax rates when there is unemployment with capital and firm mobility.

\footnotetext{
${ }^{3}$ Issues of optimal taxation in the presence of mobile capital and unemployment have previously been analysed exclusively in collective bargaining frameworks. See, among others, Fuest and Huber (1999), Boeters and Schneider (1999), Lorz and Stähler (2001), Koskela and Schöb (2002b) and Richter and Schneider (2001). Wilson (1990) analyses tax competition in an efficiency wage model, but presumes a two-sector economy, in which a monitoring problem exists solely in the primary sector. Thus, workers who do not find a job in the primary obtain employment in the secondary sector. Accordingly, Wilson's analysis does not deal with the topic of interest of the present paper, namely the impact of unemployment on the gains and losses from capital taxation and tax coordination in an open economy.
} 
The paper is structured as follows. Section 2 presents the workhorse model of unemployment and derives the political equilibrium in the absence of firm mobility. We discuss the structure of the fiscal scenarios that we analyse at the beginning of Section 3 and then characterise fiscal policy in the presence of firm immobility. Section 4 extends the analysis to a setting in which firms can migrate. Section 5 concludes.

\section{The model}

Consider a small open economy which competes for mobile capital on an international market, taking world-market prices as given. World capital supply is fixed. To focus on the impact of unemployment on the welfare effects of a strategic use of tax policy and tax harmonisation, identical countries are assumed. In the initial set-up firms are immobile and their number is given.

The country under investigation is inhabited by a continuum of internationally immobile and identical individuals. We allow individuals to choose their work effort, i.e. the qualitative component of labour supply, and suppose that its quantitative counterparts, that is participation and hours, are fixed. Effort choices are an employee's private information. Since providing effort creates disutility, employees have an incentive to deliver as little effort as possible if no costs are associated with low effort. For simplicity, let us assume that effort can only take two values, zero or the positive and exogenously given level required by firms. To provide employees with an incentive not to shirk and to deliver the required effort, a firm attempts to pay a wage above the wage paid by other firms. The wage differential generates a loss to a worker who is caught providing too little effort and fired for doing so. The desire of each individual firm to exceed the equilibrium wage results in an efficiency wage in excess of the market clearing level. This entails unemployment. Thus, in equilibrium the possibility of not being employed due to a job loss replaces the wage differential as the incentive which induces workers to provide the required level of effort.

In line with the approach which has generally been employed in the analysis of optimal taxation in the presence of labour market imperfections, unemployment takes the form of the labour supply of each individual worker only being in demand to a certain extent. Accordingly, individuals are identical not only ex ante but also ex post. This simplification allows to model the government's optimisation problem in terms of a representative agent. ${ }^{4}$

\footnotetext{
${ }^{4}$ See, for example, Fuest and Huber (1999), Koskela and Schöb (2002b), Richter and Schneider (2001), and Kleven and Sørensen (2003).
} 


\section{Government}

In each country a national authority (government) uses a source-based tax, $t^{s}$, on capital $k$, wage taxation, $t^{w}$, and a tax on profits in order to finance the public good, $g$, and unemployment benefits, $B$. Let $n$ depict the employment rate in the economy and assume that each individual supplies one unit of labour but cannot be fully employed due to the monitoring problem. Using the private good as the numeraire and formulating our discussion in terms of unit taxation, the public budget constraint is

$$
g+B(1-n)=t^{w} n+t^{s} k+t^{p}
$$

where $t^{p}$ is the revenue from profit taxation. ${ }^{5}$

\section{Households}

As in the original model by Shapiro and Stiglitz (1984), individuals are risk-neutral, infinitely lived and discount future payments with the rate $R, R>0$. They receive interest income for each unit of their capital endowment at the going world interest rate which equals the discount rate. ${ }^{6}$ The instantaneous utility, $U$, of an individual consists of the monetary income and public good consumption, $g$, less the disutility from effort, $e$, which either conforms to the level required by firms, $\bar{e}>0$, or equals its minimum level, $e=0$. If an individual is employed, she will obtain the net wage, $w-t^{w}$, receive the return from the capital endowment, and any profits net of profit taxation, $\pi$. The instantaneous utility of an individual who provides the required level of effort can, hence, be expressed as:

$$
U(\bar{e})=\left(w-t^{w}\right)+R k+\pi-\bar{e}+g .
$$

A job loss can occur for two distinct reasons. Individuals might shirk and are caught doing so with probability $c$ per unit of time. Alternatively, there might be an exogenous shock which induces the firm to dismiss workers. The respective probability for a job loss is $b$. The probabilities $b$ and $c$ are sufficiently small, implying that the time periods under consideration are short, such that $b c \approx 0$. Accordingly, the expected life time utility of an employed non-shirker, $V^{e n}$, can be expressed as $V^{e n}(\bar{e}) R=w-t^{w}-\bar{e}+$

\footnotetext{
${ }^{5}$ Since our focus is on the efficiency properties of the optimal tax structure we will, in line with the previous literature (e.g., Koskela and Schöb, 2002a, Koskela and Schöb, 2002b), focus on tax structures at given levels of $g$ and $B$.

${ }^{6}$ The model implies that all individuals have the same ownership stake in domestic firms which are fully owned by residents. This allows to concentrate on the efficiency effects of taxation in an open economy with unemployment and makes tax exportation irrelevant. See Huizinga and Nielsen (1997) for a discussion of tax policy with cross-ownership of firms.
} 
$R k+\pi+g+b\left(V^{u}(\bar{e})-V^{e n}(\bar{e})\right)$, where $V^{u}(\bar{e})$ is the utility from being unemployed, which may depend on the choice of effort. Solving for $V^{e n}(\bar{e})$ yields:

$$
V^{e n}(\bar{e})=\frac{U(\bar{e})+b V^{u}(\bar{e})}{b+R} .
$$

A shirker exerts an effort level of $e=0$, also in any future job, and loses the job with probability $b+c$, but is otherwise identical to a non-shirker. The discounted utility stream of an employed shirker $V^{e s}(0)$ is then given by:

$$
V^{e s}(0)=\frac{w-t^{w}+R k+\pi+g+(b+c) V^{u}(0)}{b+c+R} .
$$

An unemployed individual does not receive wage income and incurs no disutility from providing effort. The unemployed receives benefits, $B$, in addition to capital and any profit income. ${ }^{7}$ Otherwise, the instantaneous utility is independent of the employment status.

The endogenously determined probability that a worker who has lost the job obtains a new one, the job acquisition rate, is denoted by $a$. The discounted utility stream of an unemployed non-shirker $V^{u}(\bar{e})$, who also provides the required level of effort $\bar{e}$ in a future job, therefore, is

$$
V^{u}(\bar{e})=\frac{B+R k+\pi+g+a V^{e n}(\bar{e})}{a+R} .
$$

The utility stream for a shirker is defined accordingly. The wage which warrants a positive level of effort by workers is defined by $V^{e n}(\bar{e}) \geq V^{e s}(0)$. Solving the equality for $w$ yields:

$$
w=B+\bar{e}+\frac{\bar{e}}{c}(a+b+R)+t^{w}
$$

The efficiency wage is independent of capital income, profits and public good consumption because variations in these variables affect the utility from shirking and providing effort equally.

\footnotetext{
${ }^{7}$ In the present setting, positive transfers to unemployed, called unemployment benefits, cannot be derived as a consequence of optimal government behaviour. However, unemployment benefits are a fact of real life, and we have included them into our analysis for this reason. As long as there is a public sector revenue requirement, the level of unemployment benefits does not affect our conclusions in a world without firm mobility. In the presence of firm mobility (see Section 4) some predictions require an upper bound on unemployment benefits. Thus, we assume a positive level of transfers to unemployed throughout the paper.
} 
A steady-state on the labour market requires that inflows into and outflows from unemployment are equal. Since labour supply is normalised to unity unemployment (or the unemployment rate) $u$ is given by $u=1-n$. Because, moreover, no worker shirks in equilibrium, the steady-state equilibrium condition is $b(1-u)=b n=a(1-n)$. Substituting for $a$ in equation (6), and thus assuming that the probability of a job loss is determined endogenously, yields:

$$
w=B+\bar{e}+\frac{\bar{e}}{c}\left(\frac{b}{1-n}+R\right)+t^{w} .
$$

The efficiency wage rises with unemployment benefits $B$, the required level of effort $\bar{e}$ and the interest rate $R$, since variations in these variables imply that the utility from shirking increases relative to that of non-shirking. Moreover, as previously shown by Shapiro and Stiglitz (1984), a finite wage requires a positive unemployment rate $u=1-n$.

For later use it is helpful to explicitly compute the utility stream from employment, $V^{e n}(\bar{e})$, and unemployment, $V^{u}(\bar{e})$, as functions of the exogenous variables. Substituting $V^{u}(\bar{e})$ from equation (5) into the expression for $V^{e n}(\bar{e})$ from equation $(3)$ - or vice versa -, solving the resulting expression and using (7) to replace for the efficiency wage gives:

$$
V^{e n}(\bar{e})=k+\frac{g+B+\pi}{R}+\frac{\bar{e}}{c R}\left(\frac{b n}{1-n}+R\right)=V^{u}(\bar{e})+\frac{\bar{e}}{c} .
$$

In equilibrium, the (discounted) utility stream from being employed and not shirking exceeds the utility of an unemployed worker by the present value of the disutility of $\bar{e} / c$, which a shirker - who is fired with probability $c$ - does not incur.

\section{Production}

There are many identical firms which use capital, $k$, and effective labour, $v:=\bar{e} n$, as inputs. The production function $f(v, k)$ can be interpreted as representing the technology of a single firm or as the aggregate production function of a set of identical firms. It is homogeneous of degree $m \leq 1$ in $\{v, k\}$, for $f_{i i}<0 \forall i=v, k$, where subscripts denote partial derivatives. Implicitly, $m<1$ presumes the use of a third factor of production such as land which gives rise to pure profits. Accordingly, our subsequent analysis will distinguish between the two cases of zero and positive profits. The Euler theorem then implies

$$
\varrho:=v f_{v v}+k f_{v k} \leq 0, \quad \beta:=v f_{k v}+k f_{k k} \leq 0, \quad \omega:=f_{v k}^{2}-f_{v v} f_{k k} \leq 0
$$


where $f_{k v}=f_{v k}$ from Young's theorem. The equalities in (9) will hold if the production function is linear homogeneous in $v$ and $k$, while the inequalities will apply if it exhibits decreasing returns to scale. Let us assume, furthermore, that capital and effective labour are complements. ${ }^{8}$ Firms maximize after-tax profits $\pi:=$ $\max \left[f(v, k)-w n-\left(R+t^{s}\right) k-t^{p}\right]$. Using (7) in the profit definition, we obtain the following first-order conditions

$$
\begin{aligned}
(n): & \bar{e} f_{v}-B-\bar{e}-\frac{\bar{e}}{c}\left(R+\frac{b}{1-n}\right)-t^{w} & =0, \\
(k): & f_{k}-R-t^{s} & =0 .
\end{aligned}
$$

Since unemployment is given by $u=1-n$ and because the marginal product of capital and labour depends on unemployment and capital input, the model implies that unemployment, capital input and the efficiency wage are determined jointly in equilibrium.

Let us now determine the response of firms to a change in taxation. Inspection of (10) already shows that $t^{p}$ has no substitution effect on the factor demand decisions. Differentiating (10) and the definition of net profits, having substituted for the efficiency wage in the latter in accordance with equation (7), we get

$$
\left[\begin{array}{ccc}
\bar{e}\left(\bar{e} f_{v v}-\frac{b}{c(n-1)^{2}}\right) & \bar{e} f_{v k} & 0 \\
\bar{e} f_{v k} & f_{k k} & 0 \\
0 & 0 & -1
\end{array}\right]\left[\begin{array}{l}
d n \\
d k \\
d \pi
\end{array}\right]=\left[\begin{array}{lll}
0 & 1 & 0 \\
1 & 0 & 0 \\
k & n & 1
\end{array}\right]\left[\begin{array}{l}
d t^{s} \\
d t^{w} \\
d t^{p}
\end{array}\right]
$$

We may define for convenience $H:=b f_{k k}+c \bar{e} \omega(n-1)^{2}<0$, where the inequality follows from (9). Applying Cramer's rule to (11), and maintaining the assumptions used to derive (9), we find

$$
\begin{aligned}
n_{t^{s}} & =\frac{c}{H} f_{v k}(n-1)^{2}<0, & n_{t^{w}} & =-\frac{c}{\bar{e} H} f_{k k}(n-1)^{2}<0, \\
k_{t^{s}} & =\frac{1}{H}\left(b-c \bar{e} f_{v v}(n-1)^{2}\right)<0, & k_{t^{w}} & =\frac{c}{H} f_{v k}(n-1)^{2}<0, \\
\pi_{t^{s}} & =-k<0, & \pi_{t^{w}} & =-n<0,
\end{aligned}
$$

and short inspection shows that $n_{t^{p}}=k_{t^{p}}=0, \pi_{t^{p}}=-1$, which is suggestive from the arguments given prior to (11).

\footnotetext{
${ }^{8}$ Hence, $f_{i j}>0 \forall i \neq j=v, k$. This assumption is fulfilled for standard production functions, such as Cobb-Douglas and CES.
} 


\section{Political Equilibrium}

The government in each country maximizes the average discounted utility of an individual $n V^{e n}+(1-n) V^{u}$ subject to the per-capita revenue requirement (1), taking as given private sector actions and the tax rates chosen by the other countries. ${ }^{9}$

Let us denote the vector of policy instruments by $x:=\left(t^{s}, t^{w}, t^{p}\right)$. We may then write the Lagrangian for the government in the small country as

$$
\mathcal{L}(x, \lambda)=n V^{e n}+(1-n) V^{u}-\lambda\left(g+B(1-n)-t^{w} n-t^{s} k-t^{p}\right),
$$

where $\lambda$ is the Lagrange parameter on the revenue constraint. Using (8) to substitute out for $V^{e n}$ and $V^{u}$ in (13) we arrive at

$$
\begin{aligned}
\mathcal{L}(x, \lambda)=\frac{R k+\pi(x)+g+B}{R} & +\frac{\bar{e}}{c R}\left(R+\frac{b}{1-n(x)}\right) n(x) \\
& -\lambda\left(g+B(1-n(x))-t^{w} n(x)-t^{s} k(x)-t^{p}\right) .
\end{aligned}
$$

After differentiation we obtain the following first-order conditions

$$
\begin{aligned}
\mathcal{L}_{t^{p}} & =\lambda-\frac{1}{R} \geq 0 \\
\mathcal{L}_{t^{s}} & =\frac{b \bar{e} n_{t^{s}}+(n-1)^{2}\left(c \pi_{t^{s}}+\bar{e} R n_{t^{s}}\right)}{c(n-1)^{2} R}+\lambda\left(n_{t^{s}}\left(B+t^{w}\right)+t^{s} k_{t^{s}}\right)+\lambda k=0, \\
\mathcal{L}_{t^{w}} & =\frac{b \bar{e} n_{t^{w}}+(n-1)^{2}\left(c \pi_{t^{w}}+\bar{e} R n_{t^{w}}\right)}{c(n-1)^{2} R}+\lambda\left(n_{t^{w}}\left(B+t^{w}\right)+t^{s} k_{t^{w}}\right)+\lambda n=0,
\end{aligned}
$$

where we have used the result $n_{t^{p}}=k_{t^{p}}=0$ from the discussion of the firm's first-order conditions (10) and $\pi_{t^{p}}=-1$ in the derivation of (15a). ${ }^{10}$ The interpretation of (15a) is straightforward. A marginal increase in the profit tax reduces net private consumption by exactly the present value of the public revenue gained. If, however, $t^{p}$ is bounded, then $\mathcal{L}_{t^{p}}>0$ will hold, resulting in $\lambda>1 / R$. The argument is that the marginal costs of public funds, measured by $\lambda$, increase when public expenditure exceeds the revenue from profit taxation. In this case, the equilibrium value of $\lambda$ is given by the first-order conditions (15b) and (15c), according to which the government trades the change in 'private' utility of residents (given by the fractions) against the utility from an increase

\footnotetext{
${ }^{9}$ Since payoffs do not change over time, the maximisation of the weighted sum of instantaneous utilities from employment and from unemployment is equivalent to maximising discounted utility streams.

${ }^{10}$ The assumption that labour and capital are complements is a sufficient but not a necessary condition for the existence of an interior solution for $t^{s}, t^{w}$. To see this, use the result that $\lambda \geq 1 / R$ and (12) in $(15 \mathrm{~b})$ and $(15 \mathrm{c})$.
} 
in tax revenue caused by a change in $t^{w}$ and $t^{s}$. The latter is evaluated at the equilibrium level of $\lambda$.

Using the results given by (12) in equations (15) yields the set of first-order conditions which we employ subsequently to characterise the tax policy chosen by the government of a small country in a world with tax competition and unemployment:

$$
\begin{aligned}
\mathcal{L}_{t^{p}} & =\lambda-\frac{1}{R} \geq 0, \\
\mathcal{L}_{t^{s}} & =\frac{\alpha \bar{e} f_{k k}+k H}{R H}+\lambda\left[k+\frac{t^{s} b+c(n-1)^{2}\left(f_{v k}\left(B+t^{w}\right)-t^{s} \bar{e} f_{v v}\right)}{H}\right]=0, \\
\mathcal{L}_{t^{w}} & =-\frac{\alpha f_{k k}+n H}{R H}+\lambda\left[n-\frac{c(n-1)^{2}\left(f_{k k}\left(B+t^{w}\right)-t^{s} \bar{e} f_{v k}\right)}{\bar{e} H}\right]=0,
\end{aligned}
$$

where we use $\alpha:=b+(n-1)^{2} R>0$ in (16) for notational convenience.

\section{$3 \quad$ Nationally optimal tax rates}

In this section we characterize the tax structure under the assumption that firms are immobile. Initially, we presume that profit taxation contributes to tax revenues. As a benchmark, Proposition 1 describes the tax structure for a setting in which profits, capital and labour can be taxed. Because the profit tax is non-distortionary in the absence of firm mobility, the best that policy can do is to replicate this tax scenario. Against this benchmark, we can then discuss the factors that influence utility of the representative agent. Proposition 2 summarises our findings for a setting in which the government is constrained in the choice of wage taxation. Subsequently, we analyse tax equilibria either in the absence of profits or a tax on profits. Proposition 3 summarises the findings for a standard zero profit economy. Since the availability of optimal profit taxation rests on the strong assumption that fiscal authorities have available the necessary information to calculate the profit tax base, Proposition 4 focuses on an economic environment in which this tax not present. In Section 4 we reduce the level of abstraction further by allowing for firm mobility to test the robustness of the results discussed in the previous literature. This allows to gain insights into the economic forces that shape the choice of tax rates when fiscal decision-making is decentralised in a world where capital and firms are internationally mobile and the economy is characterised by unemployment.

For the scenario in which the government has control over the entire set of taxes and firms are immobile it is possible to establish: 
Proposition 1 If the government in a small country with immobile firms is able to choose $t^{p}, t^{s}$, and $t^{w}$, then it will not use the source-based capital tax and will subsidise wages in an efficiency wage setting.

Proof: To prove the first part of the Proposition, take a pair $\left\{t^{s}, t^{w}\right\}$ such that the firstorder conditions (16b) and (16c) are fulfilled. At that point we know $f_{k k} /\left(\bar{e} f_{v k}\right) \mathcal{L}_{t^{s}}+$ $\mathcal{L}_{t^{w}}=0$ must hold. We then solve this expression to obtain

$$
\lambda R t^{s}=(1-\lambda R) \beta .
$$

We find from (16a) that $\lambda=1 / R$ when profit taxation is possible and, from (9), we have $\beta<0$ when gross profits are positive. Inspection of (17) then shows that the government chooses not to tax mobile capital at source. To prove the second part, we use $\lambda=1 / R$ and $t^{s}=0$ in $\mathcal{L}_{t^{w}}$, which gives

$$
c(n-1)^{2} t^{w}=-c B(n-1)^{2}-\bar{e} \alpha .
$$

The only solution is $t^{w}<0$ as required by the proposition.

The government does not use the source-based capital tax in the presence of profit taxation in order to avoid the distortion of international capital allocation. Thus, introducing the constraint $t^{s}=0$ would not change taxing choices.

The government will neither tax wages, given that the receipts from profit taxation suffice to finance public expenditure. A tax on wages raises unemployment while profits can be taxed without such adverse consequences. Accordingly part of the revenue from profit taxation is used to subsidise wages. The explanation is that a wage subsidy increases effective labour input at a given gross wage, thereby mitigating the distortion on the domestic factor market. ${ }^{11}$ Also notice that a wage subsidy is preferable to a capital subsidy since the latter would shift income to foreign capital owners. There arise no such effects for a wage subsidy, given the immobility of labour.

A result akin to the finding summarised in Proposition 1 has been derived by Koskela and Schöb (2002b, Prop. 2) for a collective wage bargaining framework. The authors can, furthermore, show that the wage subsidy suffices to eliminate unemployment and interpret this result as a confirmation of the finding by Guesnerie and Laffont (1978) that the output of a price maker should be subsidised until the market price equals marginal

\footnotetext{
${ }^{11}$ The finding that '... wages should be subsidized, using whatever (pure) profits can be taxed away' (Shapiro and Stiglitz 1984, p. 440) for a closed efficiency-wage economy with a given capital stock can thus be confirmed for an open efficiency-wage economy characterised by capital mobility.
} 
costs in a first-best world. ${ }^{12}$ Accordingly, if the tax rate on profits is chosen optimally, the government can achieve the first-best allocation in a collective bargaining set-up. This is not feasible in the present shirking framework since the absence of unemployment is incompatible with a positive level of effort, due to the informational asymmetry about the worker's effort choice.

Richter and Schneider (2001) also analyse a mechanism of collective wage determination. Assuming that taxes are set prior to wages, a capital subsidy will raise output and employment only if a higher capital input reduces the market power of the owners of labour. ${ }^{13}$ In such a case, the capital subsidy has positive employment consequences for two reasons: first, the marginal product of capital rises and, second, the wage falls. Thus, it becomes worthwhile to incur the distortion of international capital allocation. In the present efficiency wage framework, aggregate labour demand determines the net wage, which has to be such that it guarantees a positive level of effort (cf. equation (7)). However, the net wage is not directly affected by the capital choices of firms. This explains why capital should not be subsidized in the present model. A capital subsidy is dominated by a wage subsidy.

Assume next that the government is unable to tax wages. We then get:

Proposition 2 If the government in a small country with immobile firms is able to choose $t^{p}$ such that net profits $\pi$ remain positive while the use of wage taxation is restricted, then it will subsidise capital in an efficiency wage setting.

Proof: To prove this proposition take a pair $\left\{t^{p}, t^{s}\right\}$ such that the first-order conditions (16a) and (16b) are fulfilled. Using (16a) to substitute out for $\lambda$ in (16b) and solving the resulting expression for $t^{s}$ at $t^{w}=0$, taking into account $f_{v k}>0$, we obtain

$$
t^{s}=-\frac{f_{v k}\left(B c(1-n)^{2}+\bar{e} \alpha\right)}{b-c \bar{e} f_{v v}(1-n)^{2}}<0 .
$$

The intuition behind the above proposition is that the tax on profits finances the government's entire expenditure for the public good and unemployment benefits. In the absence of the wage tax, the government cannot directly alleviate the unemploy-

\footnotetext{
${ }^{12}$ Related, Myles (1989) and Konishi (1990) show that fiscal policy can also be used to counteract the efficiency losses generated by imperfect competition on output markets. Konishi (1990) shows in a model where a competitive sector produces intermediate goods for a free-entry Cournot oligopoly that welfare can be raised by the taxation of intermediate goods. In contrast, however, the tax system should reduce the externalities caused by the monitoring problem on the labour market in our model.

${ }^{13}$ If taxes and wages are determined simultaneously, the tax on capital (labour) will be zero (negative). See also Boeters and Schneider (1999) and Fuest and Huber (1999).
} 
ment problem by a wage subsidy. Although a capital tax distorts international capital allocation, subsidising capital is preferable to abstaining from such a policy because it raises labour demand, $n_{t^{s}}<0$. Hence, Proposition 2 demonstrates that the gain from a capital subsidy due to lower unemployment more than compensates the costs in terms of a distortion in capital allocation. ${ }^{14}$

The analysis so far has been based on the assumption that revenues from profit taxation are positive. Assume next that the allocation described in Proposition 1 is not feasible because firms do not make profits. Then, the following result can be established:

Proposition 3 Assume that the production function exhibits constant returns to scale. Then, the government in a small country characterized by immobile firms and efficiency wages does not use the source-based capital tax and taxes wages to finance the revenue requirement.

Proof: Gross profits are zero when the production function is constant returns to scale, implying that (9) holds with equality. Inspection of (17) then shows that $t^{s}=0$, implying that wage taxation is used by the government to fulfil the public revenue requirement in (1).

The intuition for Proposition 3 is that a distortion of international capital allocation remains undesirable. However, in contrast to the assumptions on which Proposition 1 is based, the government has to tax wages in order to finance its outlays, despite the positive wage and negative output consequences of a tax on labour income. A wage tax is preferable to a tax on capital for two reasons: first, a capital tax distorts international capital allocation, while there are no such effects for immobile labour. Second, a tax on wages raises the efficiency wage (cf. equation (7)), entailing a fall in employment. Lower employment, in turn, reduces wages. Thus, the negative impact of the wage tax is mitigated. Since capital is perfectly mobile, a capital tax would not have such a price effect.

The results summarised in Proposition 3 may be related to a finding by Shapiro and Stiglitz (1984) according to which the market equilibrium will maximise expected welfare if labour is the only input, the production function is linearly homogeneous and unemployment benefits are zero. This is the case because the zero profit constraint implies that all economic surplus accrues to workers, while the absence of any distortionary government activity ensures that the surplus is maximised. In our setting, the government needs to obtain revenues. Hence, taxes exist. However, the non-distortionary profit tax

\footnotetext{
${ }^{14}$ If, however, capital and labour were substitutes, $f_{v k}<0$, contrary to our assumption, labour demand would decline with a capital subsidy. In this case, capital would be taxed, since this distortion of capital allocation would help to lower unemployment.
} 
is unavailable by assumption. Accordingly, starting from the market equilibrium without taxes as reference point, the least distortionary tax has to be selected to fulfil the government's revenue need. This is the tax on wages, despite its adverse labour market consequences, because the price effect of lower demand only occurs for the immobile factor labour but not the mobile one capital.

The last scenario to be investigated in this section is one in which profits are positive but cannot be taxed. We then have:

Proposition 4 Assume $t^{p}=0$ and that gross profits are positive. Then, the government taxes capital at source in an efficiency wage world with immobile firms, even when the country is small and the country is faced by an infinite elastic supply response on the world capital market.

Proof: Recall that in expression (9) the inequality sign applies when gross profits are positive and that $\lambda>1 / R$ when $t^{p}$ is bounded. Then, (17) can only be fulfilled for $t^{s}>0$ as required by the Proposition.

The result is interesting for two reasons. First, since the government subsidises wages in the presence of profit taxation, an immediate implication of Proposition 4 is that welfare is lower in the case of restricted profit taxation. Second, Proposition 4 at first sight stands in contrast to the results derived in Razin and Sadka (1991) and Bucovetsky and Wilson (1991). These models are based on a constant returns to scale production function and demonstrate that a small country, which faces an infinitely elastic supply of capital on the world market, taxes wage income when the only tax on capital is source-based. The contrast in results is due to the fact that profits are positive in our model, and the economic intuition can be explained as follows. An increase in sourcebased capital taxation drives capital out of the country until the marginal productivity of capital equals its tax inclusive costs. Hence, wages and profits adjust in the present model. The argument clarifies that, in principle, the wage effect of an increase in sourcebased capital taxation can be replicated by a wage tax. However, wage taxation avoids the loss in production efficiency caused by source-based capital taxation. This makes intuitive that governments choose not to tax capital at source in models in which the level of profits is zero. In the present model, an isolated increase of the source-based capital tax also causes a capital outflow and induces a loss in production efficiency. Here, however, the tax burden of source-based capital taxation is partly born by profits. Hence, the source-based capital tax acts as an indirect tax on profits and wage income, which explains why this tax is used in the absence of a direct profit tax, even in a small open economy. This suggests that it is not the presence of labour market imperfections 
per se which generates a positive source-based capital tax in the first place, but the existence of untaxed profits.

In the related literature, Richter and Schneider (2001, Prop. 9) conclude in a model with collective wage setting that governments will tax capital if wages are not decreasing with capital. However, the government may find it attractive to (implicitly) restrict wage claims by subsidising capital in an environment where the wage rate decreases with the capital employed in firms. Moreover, Koskela and Schöb (2002b, Prop. 3) demonstrate in a model of wage bargaining that we should observe source-based capital taxes if it is not profitable to restrict the power of unions through a source-based capital subsidy.

Turning to the optimal level of wage taxation in our model, intuitively, two counteracting effects are relevant for the government's choice. First, increasing the wage tax at a given level of public spending allows to reduce the source-based capital tax. Second, wage taxation increases the efficiency wage which will lead to a higher level of unemployment and, at the same time, an increasing part of profits will not even be taxed indirectly. We are not able to obtain unambiguous results with respect to the sign of the wage tax in a model which encompasses both positive and negative effects from wage taxation. ${ }^{15}$

We may now summarise our discussion with a concluding Proposition on the welfare implications of tax harmonization:

Proposition 5 Starting from an equilibrium without tax coordination, a simultaneous increase of the source-based capital tax in all countries is welfare improving in an efficiency wage economy with immobile firms, given the available taxes.

Proof: Recall that world capital supply is given. Hence, if all countries are unified in a single country, then the source-based capital tax will be lump-sum. However, Proposition 1 clearly demonstrates that fiscal authorities choose not to levy the source-based capital tax in scenarios with decentralized tax setting when the profit tax is also available. Since fiscal authorities are not indifferent in their fiscal choices, the openness of a country and, thus, the degree of tax competition has an effect on the tax structure chosen by each government, as required by the Proposition.

In models of tax competition with competitive labour markets the intuition for the welfare enhancing impact of a coordinated increase in source-based capital taxation is that a simultaneous tax increase in all jurisdictions prevents the tax-driven reallocation of

\footnotetext{
${ }^{15}$ For a given source-based tax $t^{s}>0$ according to Proposition 4, from (16b) and (16c) the wage tax can be calculated as $t^{w} \frac{c}{\bar{e}}=-\left[\frac{c B}{\bar{e}}+\frac{\alpha}{(1-n)^{2}}+t^{s}\left\{\frac{b(1+n)+(1-n)^{2}(R-c \beta)}{\varrho(1-n)^{2}}\right\}\right]$, which cannot be signed since the term in curly brackets is negative for positive gross profits from (9).
} 
capital. In the presence of unemployment, the positive welfare effects of tax coordination are strengthened since coordination of capital taxation not only allows for a welfare enhancing introduction of a source-based capital tax but also enables the government to reduce wage taxation and thereby to increase employment. In this sense, labour market imperfections and the mobility of tax bases are 'additive' in their effects on welfare. One might also interpret Proposition 5 as indicating the existence of a double dividend from tax coordination. Accordingly, measures of international tax coordination are not a substitute for reforms of domestic labour markets. Instead, globalisation of tax bases stresses the need for such reforms.

\section{$4 \quad$ Firm mobility}

This section extends the model outlined in Section 3 by introducing firm mobility. The extension takes into account the empirical feature that not only capital but also firms migrate across borders. Moreover, the results of the previous section depend to a large extent on the availability of the profit tax. However, this tax will no longer be lumpsum in the presence of firm mobility and, accordingly, increasing the tax has adverse consequences on employment which are absent without firm mobility. In this section we, therefore, examine the explanatory power of the previous literature on tax competition which often does not distinguish between firm and capital mobility. ${ }^{16}$

Assume that firms are guaranteed a fixed level of profits $\bar{\pi}$ on the world market. Given perfect international firm mobility, net profits earned by firms in the small country under consideration have to equal $\bar{\pi}$. Otherwise a reallocation of firms would be profitable. Hence, the locational choice by firms can be described by the arbitrage condition $\bar{\pi}=\pi$.

In a world without firm mobility, employment, capital and the level of profits are determined endogenously. In the presence of firm mobility the number of firms operating in the economy replaces profits as an endogenous variable. Let us denote the number of firms by $\kappa$. The equilibrium of the economy is determined by appropriately adjusted equations (7), (10a), (10b) and the arbitrage condition $\bar{\pi}=\pi$ (cf. Appendix B for the detailed calculations).

\footnotetext{
${ }^{16}$ Exceptions are Richter (1994), Wellisch (1995), Richter and Wellisch (1996) as well as Genser and Haufler (1996). The focus in these models, however, is on economic environments where tax revenues are used to finance local public inputs, or on commodity taxation while labour markets are assumed to be competitive. International household mobility can also severely change the structure of the taxing problem. See the detailed discussion in Burbidge and Myers (1994) and Wellisch (1994).
} 
We can then express the Lagrangian for the government as:

$$
\mathcal{L}(x, \lambda)=n \kappa V^{e n}+(1-n \kappa) V^{u}-\lambda\left(g+B(1-\kappa n)-t^{w} \kappa n-t^{s} \kappa k-t^{p} \kappa\right),
$$

where $\lambda$ is the Lagrange parameter on the revenue constraint. We use the expression for the utility stream of a non-shirker to substitute out for $V^{e n}$ and $V^{u}$ in (18), exploit the comparative statics derived in Appendix B (see (A.5)) after differentiation, and obtain the following conditions:

$$
\begin{aligned}
\mathcal{L}_{t^{w}}= & -\frac{b v+(c \pi+v R) \gamma}{b v R}-\lambda\left(\kappa n-\frac{c\left(t^{p}+k t^{s}+n t^{w}\right) \gamma}{b v}\right)=0, \\
\mathcal{L}_{t^{s}}= & -\frac{\pi \beta \kappa}{v^{2} R \omega}-\frac{k(v+(c \pi+v R) \gamma)}{b v n R}+\lambda\left(k \frac{b v n \kappa-c\left(t^{p}+k t^{s}+n t^{w}\right) \gamma}{b v n}\right) \\
& +\lambda\left(\kappa \frac{B n \beta+f_{k k} k^{2} t^{s}-v^{2} f_{v v} t^{s}-\beta\left(t^{p}+2 k t^{s}\right)}{v^{2} \omega}\right)=0, \\
\mathcal{L}_{t^{p}}= & -\frac{\pi f_{k k} \kappa}{v^{2} R \omega}-\frac{k(v+(c \pi+v R) \gamma)}{b v n R}+\lambda\left(\frac{b v n \kappa-c\left(t^{p}+k t^{s}+n t^{w}\right) \gamma}{b v n}\right) \\
& +\lambda\left(\kappa \frac{B n f_{k k}-f_{k k} t^{p}-\beta t^{s}}{v^{2} \omega}\right)=0,
\end{aligned}
$$

where we define $\gamma:=(\kappa n-1)^{2}>0$ and make use of (9). In the previous analysis, we have differentiated between constant and diminishing returns to scale. Notice, however, that this distinction is not an illuminating one in the presence of firm mobility since otherwise profits would be tied down by a technological constraint to $\pi=0$ and to $\pi=\bar{\pi}$ by a firm mobility restriction. Accordingly, we concentrate on a setting with diminishing returns and positive profits, i.e. $\bar{\pi}=\pi>0$. This implies $\varrho, \omega, \beta<0$ from (9). We obtain from (19a)-(19c):

$$
\begin{aligned}
\mathcal{L}_{t^{p}}-\frac{\bar{e}(c \pi+v R) \omega \gamma+b\left(v \bar{e} \omega+f_{k k} \pi \kappa\right)}{v \omega(b v+(c \pi+v R) \gamma)} \mathcal{L}_{t^{w}} & =0, \\
\mathcal{L}_{t^{p}}-\frac{\bar{e}(c \pi+v R) \omega \gamma+b\left(v \bar{e} \omega+f_{k k} \pi \kappa\right)}{\bar{e} k(c \pi+v R) \omega \gamma+b(v \bar{e} k \omega+\pi \beta \kappa)} \mathcal{L}_{t^{s}} & =0 .
\end{aligned}
$$

The simultaneous solution of equations (20) characterises the government's choice when all tax rates are available. As a result we obtain Proposition 6, which is the analogue to Proposition 1:

Proposition 6 If the government in a small country with mobile firms is able to choose $t^{p}, t^{s}, t^{w}$, it will not levy the source-based capital tax in an efficiency wage economy. 
Moreover, if unemployment benefits $B$ are sufficiently low, the wage tax will be strictly positive.

Proof: The simultaneous solution of (20) is given by

$$
\begin{aligned}
t^{s} & =0 \\
t^{p} & =\frac{\left(B c \pi+B v R+c \pi t^{w}\right) \gamma+b v(B-\pi \kappa)}{\bar{e}(b+R \gamma)} .
\end{aligned}
$$

Setting $B$ to zero in (21b) shows that the equality can only hold for $t^{w} \leq 0$ if also $t^{p}<0$ applies. Given $t^{s}=0$, however, the government's revenue requirement cannot be warranted if all tax rates are non-positive. Hence, the assumption of $t^{w} \leq 0$ is not feasible and $t^{w}>0$ has to hold for a sufficiently low value of $B$.

A comparison of Propositions 1 and 6 shows that the introduction of firm mobility does not alter the conclusion that the source-based capital tax is not used. The economic argument that this tax distorts international capital allocation continues to apply. Assuming that the government cannot use the source-based capital tax in a setting with firm mobility and setting $t^{s}=0$ in (21) does not affect optimal taxing choices. Introducing a constraint $t^{s}=0$ accordingly does not alter the resulting allocation.

Furthermore, Proposition 6 puts into perspective the remaining part of Proposition 1 regarding wage taxation in that firm mobility may fundamentally change the trade-offs which tax policy faces. Whereas $t^{p}$ falls on pure profits in the absence of firm mobility and, therefore, allows to subsidise wages in order to reduce the adverse labour market consequences resulting from the informational asymmetry between workers and firms, the tax on profits distorts the location decisions of mobile firms in the extended framework. Accordingly, the essence of Proposition 6 is that the government may use wage taxation at a low level of unemployment benefits while profits are taxed or even subsidised to attract mobile firms. The economic argument is as follows: a rise in unemployment benefits has adverse effects on the labour market outcome at a given level of taxes. To counteract the distortions there are incentives to reduce the wage tax, and to raise the profit tax, once unemployment benefits become sufficiently high. Which of the two conflicting effects dominates cannot be ascertained analytically, as equation (21b) indicates.

The next scenario we consider is related to Proposition 2 in the previous section in which the wage tax is unavailable: 
Proposition 7 If the government in a small country with mobile firms is able to choose $t^{p}$ and $t^{s}$ while wage taxation is restricted and unemployment benefits $B$ are sufficiently low, the government will tax capital at source in an efficiency wage economy.

Proof: The relevant condition is (20b). Solving the equation for $t^{w}=0$ yields:

$$
t^{s}=\frac{f_{v k}\left(\left(B c \pi+B v R-\bar{e} R t^{p}\right) \gamma+b \bar{e}\left(B n-t^{p}-n \pi \kappa\right)\right)}{\bar{e}\left(c f_{v v} \pi+\varrho R\right) \gamma+b(\bar{e} \varrho-\pi \kappa)} .
$$

If $t^{p} \leq 0$ the government's revenue requirement will imply $t^{s}>0$, since $t^{w}=0$ by assumption. If $t^{p}>0$ and $B=0$, the numerator of (22) will unambiguously be negative as $f_{v k}>0$. Moreover the denominator is always negative, since $\gamma>0$ and the inequalities in (9) apply. Thus, irrespective of the assumption regarding the sign of $t^{p}, t^{s}>0$ holds for a sufficiently low level of unemployment benefits $B$.

In the absence of wage taxation and firm mobility, the government taxes profits and uses the proceeds to subsidise capital in order to raise employment. In contrast, if firms are mobile, a trade-off between reducing employment via driving abroad firms or capital will arise. This suggests that the source-based capital tax and the profit tax become strategic complements. The source-based capital tax is positive while the sign of the profit tax is ambiguous, given a low level of unemployment benefits. Introducing firm mobility, thus, reverses the respective finding of Proposition 2. With mobile firms it is potentionally advantageous to rely on capital taxation, even though this causes an inward shift of the country's production possibility frontier. ${ }^{17}$

The final scenario we consider is related to Proposition 4 of the previous section in which the profit tax is presumed not to be available. We then have:

Proposition 8 If the government in a small country with mobile firms is able to choose $t^{w}$ and $t^{s}$ while profit taxation is restricted and unemployment benefits $B$ are sufficiently low, the government will tax wages in an efficiency wage economy.

Proof: We use (20a) and (20b) to eliminate $\mathcal{L}_{t^{p}}$ and to solve the resulting expression to get

$$
t^{s} \bar{e}=\frac{\left(f_{k k} k+v f_{v v}\right)\left(\left(B c \pi+B v R+c \pi t^{w}\right) \gamma+b v(B-\pi \kappa)\right)}{\beta(b+R \gamma) k+\varrho((b+R \gamma) v+c \pi)}
$$

If $t^{s} \leq 0$ the government's revenue requirement implies $t^{w}>0$, since $t^{p}=0$ by assumption. Moreover, the denominator of (23) is negative, since $\gamma>0$ and the inequalities

\footnotetext{
${ }^{17}$ Related, Haufler (2001b, pp. 257) shows in a model based on Genser and Haufler (1996) that a destination-based commodity tax, which is akin to the source-based capital tax in our model, can be used as a substitute for a missing tax on non-wage income.
} 
in (9) apply. The first term in the numerator of (23) is also negative. Accordingly, for $B=0$ a positive $t^{s}$ requires $t^{w}>0$ from condition (23). Thus, irrespective of the assumption regarding the sign of $t^{s}, t^{w}>0$ holds for a sufficiently low level of unemployment benefits $B$.

The above finding should be contrasted with Proposition 4, according to which capital will be taxed at source in a setting with immobile firms while the sign of the wage tax is ambiguous. In the presence of firm mobility the wage tax will be positive, while the tax on capital cannot be signed. The economic reason is that the case for taxation of capital, as an indirect tax on profits, becomes less clear in the case of firm mobility. A positive source-based capital tax lowers employment since such a tax drives capital and firms out of the country. A wage tax, despite its more direct negative employment consequences, only has an indirect impact on profits and capital usage. Accordingly, firm mobility re-establishes the unambiguous case for wage taxation.

Finally, it is clear that a simultaneous increase in the level of profit taxation and the level of source-based capital taxation in all countries would eliminate the negative effects of tax competition. The argument is that both taxes would be lump-sum if all countries were unified in one economy. In this extended form Proposition 5 is also valid in a framework with firm mobility.

\section{Conclusions}

In this paper we analyse tax policy in the presence of unemployment due to efficiency wages and internationally mobile capital. We, furthermore, differentiate a setting in which profits can vary from a world in which profits are constant, either due to a constant returns technology or because of perfect international firm mobility. The present paper characterises optimal tax rates in each of the different cases to gain a better understanding for the economic forces that shape tax policy in an open economy which faces unemployment.

The findings of this paper for an efficiency economy under alternative assumptions regarding firm mobility and the availability of tax instruments are summarised in Table 2. Moreover, the table contains information on optimal tax rates in the absence of labour market imperfetions. First, it is seen from Proposition 4 that the source-based tax on mobile capital is used when firms are immobile and positive profit income cannot be taxed directly due to the absence of profit taxation. This result is robust with respect to the different modelling approaches for the labour market. The economic explanation for this observation is that the source-based tax on capital ultimatively falls on profits. 


\begin{tabular}{l|c|c|cc|cc|cc} 
& $\begin{array}{c}\text { Propo- } \\
\text { sition } \\
(i)\end{array}$ & Taxes & \multicolumn{5}{|c}{ Optimal tax rates } \\
available & \multicolumn{4}{|c}{$t^{s}$} & $t^{p}$ \\
1. Firms immobile, $\pi>0$ & 1 & $t^{p}, t^{s}, t^{w}$ and $t^{p}, t^{w}$ & 0 & $(0)$ & + & $(+)$ & - & $(0)$ \\
& 2 & $t^{p}, t^{s}$ & - & $(0)$ & + & $(+)$ & 0 & $(0)$ \\
& 4 & $t^{s}, t^{w}$ & + & $(+)$ & 0 & $(0)$ & $+/$ & $(+)$ \\
2. Firms immobile, $\pi=0$ & 3 & $t^{s}, t^{w}$ & 0 & $(0)$ & 0 & $(0)$ & + & $(+)$ \\
3. Firms mobile, $\pi>0$ & 6 & $t^{p}, t^{s}, t^{w}$ and $t^{p}, t^{w}$ & 0 & $(0)$ & $+/-$ & $(0)$ & + & $(+)$ \\
& 7 & $t^{p}, t^{s}$ & + & $(+)$ & $+/-$ & $(+)$ & 0 & $(0)$ \\
& 8 & $t^{s}, t^{w}$ & $+/-$ & $($ na) & 0 & $($ na) & + & $($ na)
\end{tabular}

Notes: columns (iv), (vi) and (viii) display the findings of our paper, where a $+/-/ 0$ indicates a positive/negative/zero tax rate. Ambigous signs are indicated by ${ }^{+} /{ }_{-}$. The sign of the optimal tax rates if the labour market is competitive are presented in brackets. They are taken from the literature discussed in the course of the present paper. A (na) indicates that this scenario has not yet been analysed to our knowledge.

Table 2: Summary of main results.

This clarifies that the production inefficiency attributed to the source-based capital tax cannot generally be used as an argument for the absence of capital taxation. Second, propositions 1, 2 and 4 indicate that there exist environments where the government in an efficiency wage economy chooses to subsidise wages or capital. This result cannot be observed when the labour market is assumed to be competitive. The conflict in results between our model and those in which labour markets are assumed to be competitive can be explained by the observation that both the wage and the capital subsidy increase labour demand by firms and, thus, serve as a device to counteract the distortions on the domestic labour market. Interestingly, any capital subsidy is financed by profit taxation. Of course, the use of capital taxation as a corrective device is pointless in the absence of labour-market distortions.

The remaining set of propositions particularly clarifies that the relative importance of the economic mechanisms described above crucially depends on the precise modelling of the economic environment. Extending the model by allowing for firm mobility increases the costs of profit taxation and establishes a case for taxing capital at source (see Proposition 7), even though the economy is small and perceives world capital supply to be infinitely elastic. Moreover, wages will always be taxed if firms are mobile. The interpretation of the finding is that the mobility of tax bases renders both the profit tax 
and the capital tax inferior devices to collect tax revenue, even though the wage tax has a direct negative effect on employment.

It is one of the most general results of the present paper that the welfare costs of labour market imperfections increase when tax bases become internationally mobile. The reason is that international capital or firm mobility impose a downward pressure on those taxes which are levied on mobile bases, which makes it increasingly difficult for governments to use fiscal policy to counteract the distortions on domestic markets directly through a reduction of wage taxation. Accordingly, international harmonisation of capital and profit taxation is a necessary condition for the effective use of fiscal policy to alleviate the negative welfare consequences of unemployment. High unemployment countries are more likely to profit from measures of tax harmonisation. Hence, these countries are more likely to support measures of tax harmonisation when the necessary cooperation between countries is enforced. The empirical evidence summarised in Table 1 is at least consistent with this conclusion.

While this paper has focused on specific aspects of the interaction of tax competition with unemployment, many issues are still left for future research. For instance, the analysis has assumed that individuals are identical. However, we observe heterogeneous individuals which may differ with respect to their abilities in the real world, and these differences should also be taken into account when thinking about tax policy. Moreover, given labour market imperfections, the institutional features of the unemployment insurance system may have a significant influence (e.g. Pissarides 1998, Richter and Schneider 2001). The assumption of an exogenous capital supply, which renders the residence-based capital income taxation lump-sum, may also be an important factor for the taxing choices. We believe, however, that these potential extensions of the basic model, while valuable and worth pursuing, are unlikely to change the basic mechanisms discussed in this paper. For example, when residence-based capital taxation is sustainable in a world with endogenous capital supply and decentralized tax setting, then the source-based capital tax we considered would still be used as an indirect tax on profits and we would continue to obtain the result that coordination of capital taxes is not a substitute for domestic reforms. To sum up, the simple workhorse model of the present paper allows to give an answer to the question through which channels market integration may intensify the detrimental effects of labour market imperfections. 


\section{A Appendix: Data sources for Table 1}

\begin{tabular}{|c|c|c|c|c|c|c|c|c|c|}
\hline Country & $\begin{array}{l}\text { Unemploy- } \\
\text { ment rate } \\
(1)\end{array}$ & $\begin{array}{c}\text { Total em- } \\
\text { ployment } \\
(2)\end{array}$ & $\begin{array}{l}\text { Employment in } \\
\text { 'Financial } \\
\text { Intermediation' } \\
(3)\end{array}$ & $(3) /(2)$ & Rank & $\begin{array}{l}\text { Value-added in } \\
\text { current domestic } \\
\text { prices }\end{array}$ & $\begin{array}{l}\text { Value-added in } \\
\text { 'Financial } \\
\text { Intermediation' } \\
(7)\end{array}$ & $(7) /(6)$ & Rank \\
\hline Austria & 4.3 & 3598 & 109.8 & 0.031 & 9 & 2461187 & 168015 & 0.068 & 4 \\
\hline Belgium & 11.7 & 3802.3 & 130.4 & 0.034 & 6 & 8483500 & 587058 & 0.069 & 3 \\
\hline Denmark & 5.5 & 2692 & 74 & 0.027 & 11 & 1026371 & 51270 & 0.050 & 9 \\
\hline Finland & 11.4 & 2183.6 & 41 & 0.019 & 16 & 609714 & 20956 & 0.034 & 14 \\
\hline France & 12.0 & 23155.5 & 750.2 & 0.032 & 8 & 7852505 & 354706 & 0.045 & 11 \\
\hline Germany & 9.3 & 37540 & 1256 & 0.033 & 7 & 3547540 & 169500 & 0.048 & 10 \\
\hline Greece & 11.5 & 3921 & 82 & 0.021 & 15 & 32635985 & 1445873 & 0.044 & 12 \\
\hline Ireland & 7.8 & 1155.3 & 57.8 & 0.050 & 3 & 54461.4 & 2037.1 & 0.037 & 15 \\
\hline Italy & 11.9 & 22914.5 & 633.4 & 0.028 & 10 & 1920288 & 115770 & 0.060 & 6 \\
\hline Luxembourg & 2.3 & 237 & 24 & 0.101 & 1 & 666118 & 137717 & 0.207 & 1 \\
\hline Netherlands & 4.3 & 6173.1 & 246.2 & 0.040 & 5 & 717501 & 42097 & 0.059 & 7 \\
\hline Portugal & 5.0 & 4655.7 & 101.3 & 0.022 & 13 & 17459926 & 145489 & 0.008 & 16 \\
\hline Spain & 18.8 & 14123.5 & 343.7 & 0.024 & 12 & 82872.1 & 4370 & 0.053 & 8 \\
\hline Sweden & 8.5 & 4072 & 87 & 0.021 & 14 & 1615329 & 66490 & 0.041 & 13 \\
\hline Switzerland & 3.5 & 3841 & 201 & 0.052 & 2 & 376974 & 27000 & 0.072 & 2 \\
\hline $\mathrm{UK}$ & 6.2 & 27005 & 1198 & 0.044 & 4 & 755297 & 46199 & 0.061 & 5 \\
\hline
\end{tabular}

Sources:

Unemployment rate: OECD (2001), Labour Force Statistics, 1980-2000. Tables II, unemployed in 1998 as share of civilian labour force.

Total employment and Employment in 'Financial Intermediation': OECD (2002), National Accounts of OECD Countries, Vol. 2, 1989-2000. Tables 9, Total employment in thousand persons. For Austria, Italy, the Netherlands, Portugal and Spain: full time equivalents are available and used. For Ireland only figures for employees are available. For Switzerland and the UK, data for civilian employees are used, obtained from OECD (2001), Labour Force Statistics, 1980-2000, Tables IV.

Value-added and value-added in 'Financial Intermediation': OECD (2002), National Accounts of OECD Countries, Vol. 2, 1989-2000. Tables 7. Gross value-added in 1998; Sweden (1996). Data are in current local currency (in millions, except Italy, Spain; billions). For Switzerland, the value-added for 'Financial Intermediation'has been estimated to be $25 \%$ of the sector 'Financial Intermediation, Real Estate, Renting and Business Activities' since data for 'Financial Intermediation' are not available. (OECD (2001), Labour Force Statistics, 1980-2000, p. 275).

Shares and Ranks: own calculations. Countries with ranks 1-5 (6-10/11-16) are found in the first (second/third) column of rows three (number of employees) and four (value-added) of Table 1 in the main text of Section 1. 


\section{B Appendix: Firm mobility}

The equilibrium condition for the labour market is $b \kappa n=a(1-\kappa n)$. Using this condition in equation (6) of the main text gives

$$
w=B+\bar{e}+\frac{\bar{e}}{c}\left(\frac{b}{1-\kappa n}+R\right)+t^{w} .
$$

Using (A.1) and proceeding along the lines described in the main text to derive (8) shows

$$
V^{e n}(\bar{e})=k+\frac{g+B+\pi}{R}+\frac{\bar{e}}{c R}\left(\frac{b \kappa n}{1-\kappa n}+R\right)=V^{u}(\bar{e})+\frac{\bar{e}}{c} .
$$

From the profit definition and (A.1) we obtain the following first-order conditions

$$
\begin{aligned}
(n): & \bar{e} f_{v}-B-\bar{e}-\frac{\bar{e}}{c}\left(R+\frac{b}{1-\kappa n}\right)-t^{w} & =0, \\
(k): & f_{k}-R-t^{s} & =0 .
\end{aligned}
$$

Differentiating (A.3), the definition of net profits and the arbitrage condition $\bar{\pi}=\pi$ yields

$$
\left[\begin{array}{cccc}
\bar{e}\left(\bar{e} f_{v v}-\frac{b \kappa}{c(\kappa n-1)^{2}}\right) & \bar{e} f_{v k} & 0 & -\frac{b v}{c(n \kappa-1)^{2}} \\
\bar{e} f_{v k} & f_{k k} & 0 & 0 \\
-\frac{b v \kappa}{c(n \kappa-1)^{2}} & 0 & -1 & -\frac{b c v n}{c(1-n \kappa)^{2}} \\
0 & 0 & 1 & 0
\end{array}\right]\left[\begin{array}{c}
d n \\
d k \\
d \pi \\
d \kappa
\end{array}\right]=\left[\begin{array}{lll}
0 & 1 & 0 \\
1 & 0 & 0 \\
k & n & 1 \\
0 & 0 & 0
\end{array}\right]\left[\begin{array}{l}
d t^{s} \\
d t^{w} \\
d t^{p}
\end{array}\right]
$$

Inspection of the matrix on the l.h.s. of (A.4) shows that the determinant is strictly positive when gross profits are positive. The latter implies that the inequalities in (9) apply. This determinant is $\tilde{H}:=\bar{e}^{2}\left(f_{v v} f_{k k}-f_{v k}^{2}\right)\left(\frac{b v n}{c(1-\kappa n)^{2}}\right)>0$. Applying Cramer's rule to (A.4) we get

$$
\begin{aligned}
n_{t^{s}} & =-\frac{b \beta}{c(1-\kappa n)^{2} \tilde{H}}, & n_{t^{p}} & =-\frac{b v f_{k k}}{c(1-\kappa n)^{2} \tilde{H}}, \\
k_{t^{s}} & =\frac{b v \bar{e} \varrho}{c(1-\kappa n)^{2} \tilde{H}}, & k_{t^{p}} & =\frac{b v \bar{e} f_{v k}}{c(1-\kappa n)^{2} \tilde{H}}, \\
\kappa_{t^{s}} & =-n_{t^{s}} \frac{\kappa}{n}+\kappa_{t^{w}} \frac{k(1-\kappa n)^{2}}{n}, & \kappa_{t^{p}} & =\bar{e} \frac{b f_{k k} \kappa+c \bar{e} \omega(1-\kappa n)^{2}}{c(1-\kappa n)^{2} \tilde{H}}, \\
\kappa_{t^{w}} & =\frac{\bar{e}^{2} \omega n}{\tilde{H}}, & n_{t^{w}} & =k_{t^{w}}=\pi_{t^{s}}=\pi_{t^{w}}=\pi_{t^{p}}=0 .
\end{aligned}
$$




\section{References}

Boeters, S., and K. Schneider (1999) 'Government versus union: the structure of optimal taxation in a unionized labor market.' FinanzArchiv 56, 174-187

Bucovetsky, S., and J.D. Wilson (1991) 'Tax competition with two tax instruments.' Regional Science and Urban Economics 21, 333-350

Burbidge, J.B., and G.M. Myers (1994) 'Population mobility and capital tax competition.' Regional Science and Urban Economics 24, 441-459

Eggert, W., and M. Kolmar (2002) 'Residence-based capital taxation in a small open economy: why information is voluntarily exchanged and why it is not.' International Tax and Public Finance 9, 465-482

European Commission (1998) 'Proposal for a council directive to ensure a minimum of effective taxation of savings income in the form of interest payments within the Community.' COM(1995) 295 final, Brussels

(2001) 'Proposal for a council directive to ensure a minimum of effective taxation of savings income in the form of interest payments within the Community.' $\mathrm{COM}(2001)$ 400 final, Brussels

Fuest, C., and B. Huber (1999) 'Tax coordination and unemployment.' International Tax and Public Finance 6, 7-26

Fuest, C., B. Huber, and J. Mintz (2003) 'Capital mobility and tax competition: a survey.' CESifo working paper 956

Genser, B., and A. Haufler (1996) 'On the optimal tax policy mix when consumers and firms are imperfectly mobile.' FinanzArchiv 53, 411-433

Guesnerie, R., and J.-J. Laffont (1978) 'Taxing price makers.' Journal of Economic Theory 19, 423-455

Haufler, A. (2001a) 'Regional integration and the development of tax systems in the European Union.' In Regionalism and Globalization: Theory and Practice, ed. L. Lahiri (Routledge), 261-282 
_ (2001b) Taxation in a global economy (Cambridge University Press)

Huizinga, H., and S. Nielsen (1997) 'Capital income and profit taxation with foreign ownership of firms.' Journal of International Economics 42, 149-165

Huizinga, H., and S.B. Nielsen (2003) 'Withholding taxes or information exchange: How to tax international interest flows.' Journal of Public Economics 87, 39-72

Kleven, H.J., and P.B. Sørensen (2003) 'Labour tax reform, the good jobs and the bad jobs.' Scandinavian Journal of Economics. forthcoming

Konishi, H. (1990) 'Final and intermediate goods taxes in an oligopolistic economy with free entry.' Journal of Public Economics 42, 371-386

Koskela, E., and R. Schöb (2002a) 'Optimal capital taxation in economies with unionised and competitive labour markets.' CESifo working paper 819

— (2002b) 'Optimal factor income taxation in the presence of unemployment.' Journal of Public Economic Theory 4, 387-404

Lorz, O., and F. Stähler (2001) 'Who is afraid of capital mobility?' Journal of Economics $74,79-101$

Myles, G.D. (1989) 'Ramsey tax rules for economies with imperfect competition.' Journal of Public Economics 38, 95-115

Oates, W.E. (1999) 'An essay on fiscal federalism.' Journal of Economic Literature $37,1120-1149$

Pissarides, C.A. (1998) 'The impact of employment tax cuts on unemployment and wages: the role of unemployment benefits and tax structure.' European Economic Review 42, 155-183

Razin, A., and E. Sadka (1991) 'International tax competition and gains from tax harmonization.' Economics Letters 37, 69-76

Richter, W., and K. Schneider (2001) 'Taxing mobile capital with labor market imperfections.' International Tax and Public Finance 8, 245-262

Richter, W. F. (1994) 'The efficient allocation of local public factors in Tiebout's tradition.' Regional Science and Urban Economics 24, 323-340 
Richter, W. F., and D. Wellisch (1996) 'The provision of local public goods and factors in the presence of firm and household mobility.' Journal of Public Economics 60, 73-93

Shapiro, C., and J. E. Stiglitz (1984) 'Equilibrium unemployment as a worker discipline device.' American Economic Review 74, 433-444

Wellisch, D. (1995) Dezentrale Finanzpolitik bei hoher Mobilität (Tübingen: Mohr (Paul Siebeck))

Wellisch, D. (1994) 'Interregional Spillovers in the Presence of Perfect and Imperfect Household Mobility.' Journal of Public Economics 55, 167-184

Wilson, J.D. (1990) 'The optimal taxation of internationally mobile capital in an efficiency wage model.' In Taxation in the global economy, ed. A. Razin and J. Slemrod (Chicago: Chicago University Press) chapter 11, pp. 397-432

(1999) 'Theories of tax competition.' National Tax Journal 52, 269-304 


\section{IZA Discussion Papers}

\begin{tabular}{|c|c|c|c|c|}
\hline No. & Author(s) & Title & Area & Date \\
\hline 923 & $\begin{array}{l}\text { U. Dulleck } \\
\text { P. Frijters } \\
\text { R. Winter-Ebmer }\end{array}$ & $\begin{array}{l}\text { Reducing Start-Up Costs for New Firms: The } \\
\text { Double Dividend on the Labour Market }\end{array}$ & 5 & $11 / 03$ \\
\hline 924 & $\begin{array}{l}\text { A. P. Damm } \\
\text { M. Rosholm }\end{array}$ & $\begin{array}{l}\text { Employment Effects of Dispersal Policies on } \\
\text { Refugee Immigrants, Part I: Theory }\end{array}$ & 1 & $11 / 03$ \\
\hline 925 & $\begin{array}{l}\text { A. P. Damm } \\
\text { M. Rosholm }\end{array}$ & $\begin{array}{l}\text { Employment Effects of Dispersal Policies on } \\
\text { Refugee Immigrants, Part II: Empirical Evidence }\end{array}$ & 1 & $11 / 03$ \\
\hline 926 & $\begin{array}{l}\text { S. E. Black } \\
\text { P. J. Devereux } \\
\text { K. G. Salvanes }\end{array}$ & $\begin{array}{l}\text { Why the Apple Doesn't Fall Far: Understanding } \\
\text { Intergenerational Transmission of Human } \\
\text { Capital }\end{array}$ & 5 & $11 / 03$ \\
\hline 927 & $\begin{array}{l}\text { L. Goette } \\
\text { D. Huffman } \\
\text { E. Fehr }\end{array}$ & Loss Aversion and Labor Supply & 5 & $11 / 03$ \\
\hline 928 & $\begin{array}{l}\text { H. Selod } \\
\text { Y. Zenou }\end{array}$ & $\begin{array}{l}\text { Does City Structure Affect the Labor-Market } \\
\text { Outcomes of Black Workers? }\end{array}$ & 3 & $11 / 03$ \\
\hline 929 & $\begin{array}{l}\text { Z. Eckstein } \\
\text { G. J. van den Berg }\end{array}$ & Empirical Labor Search: A Survey & 1 & $11 / 03$ \\
\hline 930 & $\begin{array}{l}\text { M. Lindeboom } \\
\text { F. Portrait } \\
\text { G. J. van den Berg }\end{array}$ & $\begin{array}{l}\text { Individual Mortality and Macro Economic } \\
\text { Conditions from Birth to Death }\end{array}$ & 3 & $11 / 03$ \\
\hline 931 & P. Kooreman & $\begin{array}{l}\text { Time, Money, Peers, and Parents: Some Data } \\
\text { and Theories on Teenage Behavior }\end{array}$ & 5 & $11 / 03$ \\
\hline 932 & $\begin{array}{l}\text { H. N. Mocan } \\
\text { E. Tekin }\end{array}$ & $\begin{array}{l}\text { Guns, Drugs and Juvenile Crime: Evidence from } \\
\text { a Panel of Siblings and Twins }\end{array}$ & 3 & $11 / 03$ \\
\hline 933 & $\begin{array}{l}\text { W. Arulampalam } \\
\text { A. L. Booth } \\
\text { M. L. Bryan }\end{array}$ & Training in Europe & 5 & $11 / 03$ \\
\hline 934 & $\begin{array}{l}\text { M. Piva } \\
\text { E. Santarelli } \\
\text { M. Vivarelli }\end{array}$ & $\begin{array}{l}\text { The Skill Bias Effect of Technological and } \\
\text { Organisational Change: Evidence and Policy } \\
\text { Implications }\end{array}$ & 5 & $11 / 03$ \\
\hline 935 & T. J. Dohmen & $\begin{array}{l}\text { Performance, Seniority and Wages: Formal } \\
\text { Salary Systems and Individual Earnings Profiles }\end{array}$ & 1 & $11 / 03$ \\
\hline 936 & $\begin{array}{l}\text { M. K. Jones } \\
\text { P. L. Latreille } \\
\text { P. J. Sloane }\end{array}$ & Disability, Gender and the Labour Market & 3 & $11 / 03$ \\
\hline 937 & $\begin{array}{l}\text { W. Eggert } \\
\text { L. Goerke }\end{array}$ & $\begin{array}{l}\text { Fiscal Policy, Economic Integration and } \\
\text { Unemployment }\end{array}$ & 2 & $11 / 03$ \\
\hline
\end{tabular}

An updated list of IZA Discussion Papers is available on the center's homepage www.iza.org. 